
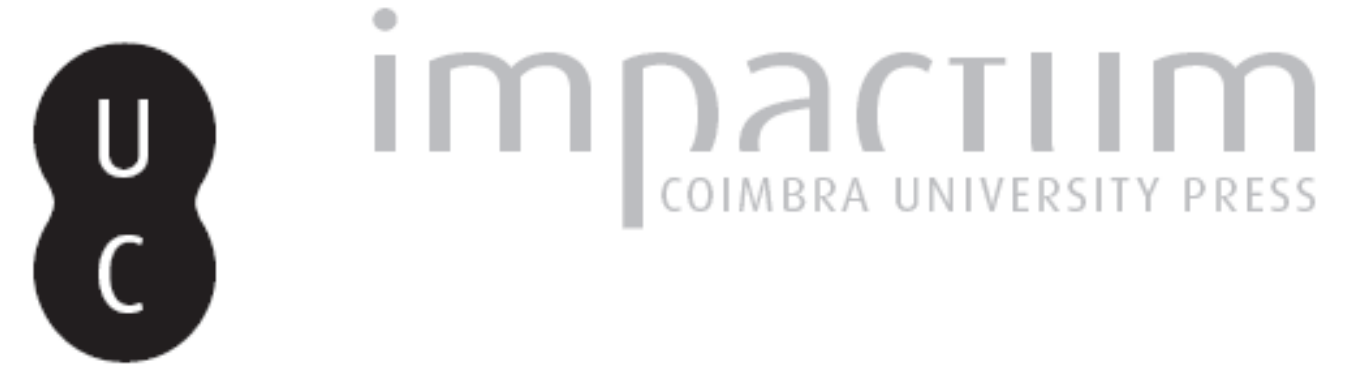

\title{
As capturas de bacias hidrográficas: evidências morfotectônicas no contato da chapada com o relevo dissecado da bacia do Rio Tijuco (MG)
}

Autor(es): $\quad$ Pereira, Kátia Gisele de Oliveira; Pedrosa, António de Sousa

Publicado por: $\quad$ Associação Portuguesa de Riscos, Prevenção e Segurança; Imprensa

URL

persistente:

da Universidade de Coimbra

DOI: $\quad$ DOI:http://dx.doi.org/10.14195/1647-7723_22_6

Accessed : $\quad$ 26-Apr-2023 14:21:08

A navegação consulta e descarregamento dos títulos inseridos nas Bibliotecas Digitais UC Digitalis, UC Pombalina e UC Impactum, pressupõem a aceitação plena e sem reservas dos Termos e Condições de Uso destas Bibliotecas Digitais, disponíveis em https://digitalis.uc.pt/pt-pt/termos.

Conforme exposto nos referidos Termos e Condições de Uso, o descarregamento de títulos de acesso restrito requer uma licença válida de autorização devendo o utilizador aceder ao(s) documento(s) a partir de um endereço de IP da instituição detentora da supramencionada licença.

Ao utilizador é apenas permitido o descarregamento para uso pessoal, pelo que o emprego do(s) título(s) descarregado(s) para outro fim, designadamente comercial, carece de autorização do respetivo autor ou editor da obra.

Na medida em que todas as obras da UC Digitalis se encontram protegidas pelo Código do Direito de Autor e Direitos Conexos e demais legislação aplicável, toda a cópia, parcial ou total, deste documento, nos casos em que é legalmente admitida, deverá conter ou fazer-se acompanhar por este aviso. 


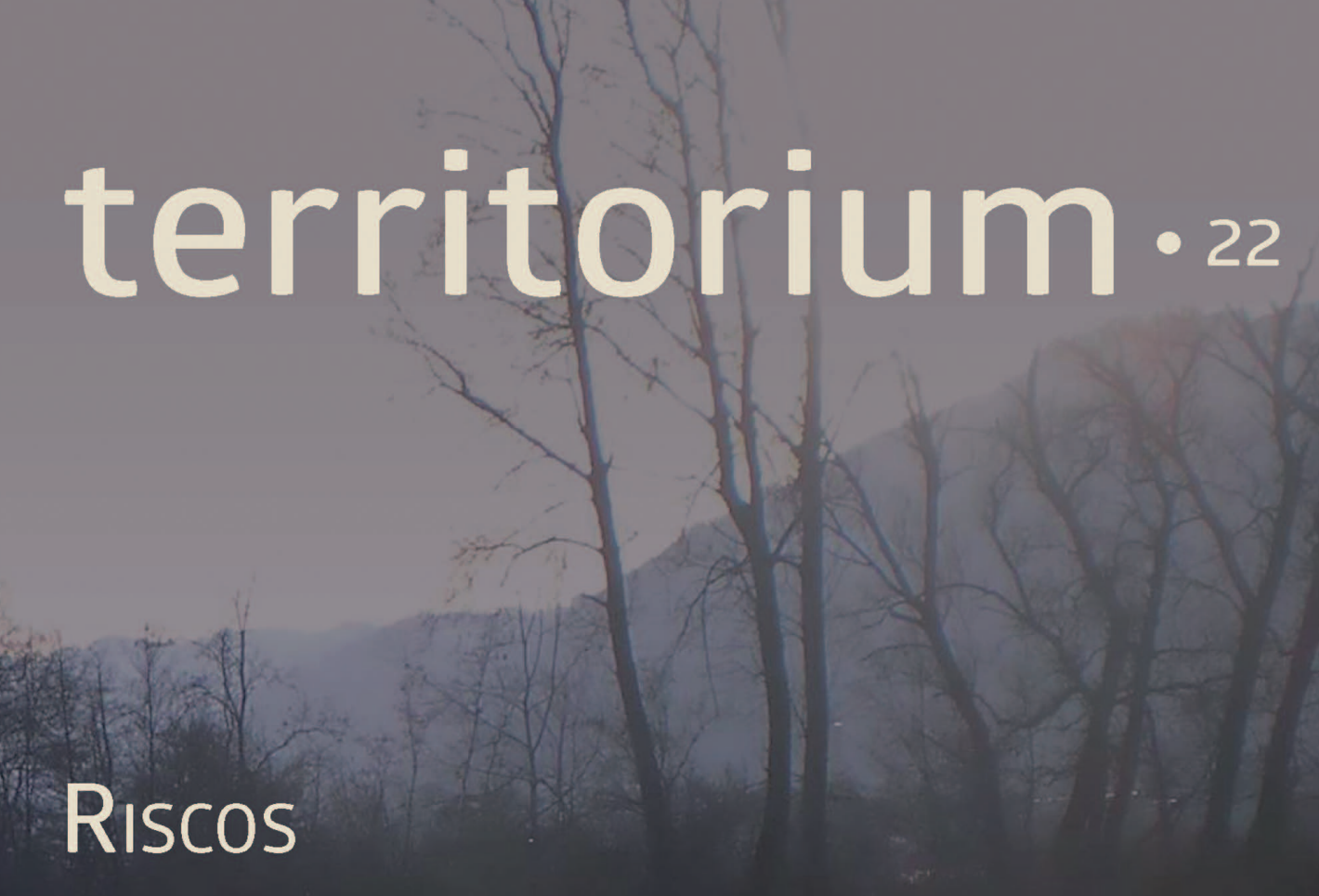

\section{TERRITÓRIOS DE CONVERGÊNCIA}

- Imprensa da Universidade de Coimbra Associação Portuguesa de:Riscos, Prevenção e Segurança 


\title{
AS CAPTURAS DE BACIAS HIDROGRÁFICAS: EVIDÊNCIAS MORFOTECTÔNICAS NO CONTATO DA CHAPADA COM O RELEVO DISSECADO DA BACIA DO RIO TIJUCO (MG)*
}

\section{THE WATERSHEDS CAPTURES: MORPHOTECTONICS EVIDENCE IN THE CONTACT OF THE PLATEAU WITH THE DISSECTED RELIEF OF TIJUCO RIVER BASIN (MG)}

\author{
Kátia Gisele de Oliveira Pereira \\ Laboratório de Análises Ambientais em Bacia Hidrográfica (FACIP/UFU) \\ katia_gisele@hotmail.com \\ António de Sousa Pedrosa (+ In Memoriam)
}

Prof. IG - UFU, RISCOS

RESUMO

A origem paleogeográfica da área de pesquisa conta com a ocorrência dos derrames vulcânicos que deram origem aos basaltos da Formação Serra Geral, rocha encontrada na base dos principais cursos d'água da região. Sobre eles ocorrem os arenitos do Grupo Bauru. Esse grupo é representado nesta área por: i) arenitos da Formação Marília; ii) a Formação Adamantina; iii) a Formação Uberaba. A área de pesquisa corresponde às bacias dos ribeirões Douradinho, Panga e Estiva, afluentes do rio Tijuco (MG), localizada no Oeste do Triângulo Mineiro no contato da chapada com o relevo dissecado do rio Tijuco (MG). Neste compartimento são encontradas intensas voçorocas alinhadas com as rupturas nas vertentes e, também, com o rebaixamento do nível de base.

Palavras-chave: Fluxo de água subsuperficial, descontinuidades litológicas, voçorocas, Bacia Bauru.

\section{ABSTRACT}

The paleogeographic origin of the survey area includes the occurrence of volcanic flows that gave rise to the basalts of the Serra Geral Formation, rock found at the base of the main streams of the region. Over them, occur the sandstones of Bauru Group. This group is represented in this area by: i) Marilia Formation sandstones; ii) Adamantina Formation; iii) Uberaba Formation. The search area corresponds to the basins of streams Douradinho, Panga and Estiva, tributaries of the Tijuco river (MG), located in the West of the Triângulo Mineiro in the contact of the dissecated plateau with the Tijuco river (MG). In this compartment are found intense gullies aligned with ruputures in the slopes, and also with the base level lowering.

Keywords: Subsurface water flow, lithological discontinuity, gullies, Bauru Basin.

\section{RESUMEN}

Captura de cuencas hidrográficas: evidencias morfotectónicas en el contacto de la Chapada con el relevo disecado de lo cuenca hidrográfica del río Tijuco (MG - El origen paleogeográfica del área de estudio incluye la ocurrencia de derrames volcánicos que dieron origen a los basaltos de la Formación Serra Geral, roca encontrada en la base de los principales cursos de agua de la región. Por encima de los basaltos ocurren areniscas del Grupo Bauru. Este grupo está representado en esta área a través de tres Formaciones: i) Marilia (areniscas); ii) Adamantina; iii) Uberaba. El área de búsqueda corresponde a las cuencas de los arroyos Douradinho, Panga y Estiva, afluentes del río Tijuco (MG), situada en el oeste del Triángulo Minero en el contacto de la Chapada con el relieve diseccado del río Tijuco (MG). En este sector se encuentran mucho barrancos alineados con roturas en las pendientes y también con el descenso del nivel de base.

Palabras clave: Flujo subsuperficial de agua, discontinuidades litológicas, barrancos, Cuenca Bauru.

\section{RÉSUMÉ}

Les captures de bassin versant: Evidences morpho tectonique dans le contact entre la "Chapada" et le relief disséqué du bassin de la rivière du Tejuco (MG) - L'origine paléogéographique de la zone d'étude comprend l'apparition de coulées volcaniques qui ont donné lieu à des basaltes de la "Formação de Serra Geral", un rocher que l'on trouve à la base des principaux cours d'eau de la région, sur lesquels se produisent les "grès du Grupo Bauru". Ce groupe est représenté dans ce domaine par: i) grès de la "Formação Marília"; ii) la "Formação Adamantina"; iii) la "Formação Uberaba". La zone de recherche correspond aux bassins des cours d'eau Douradinho, Panga et l'Estiva, affluents de la rivière Tijuco (MG), située dans l'ouest du "Triangulo Mineiro" en contact avec le relief du plateau disséqué de la rivière Tijuco (MG). Dans ce compartiment se trouvent des intenses formations de ravins alignées avec les ruptures dans les brins de la rivière et aussi avec l'abaissement du niveau de base.

Mots-clé: Écoulement souterrain de l'eau, discontinuité lithologique, ravins, Bassin de Bauru.

* O texto deste artigo corresponde a uma comunicação apresentada no III Congresso Internacional, I Simpósio Ibero-Americano e VIII Encontro Nacional de Riscos, tendo sido submetido em 30-01-2015, sujeito a revisão por pares a 30-04-2015 e aceite para publicação em 14-07-2015.

Este artigo é parte integrante da Revista Territorium, n. ${ }^{\circ} 22,2015,{ }^{\circ}$ RIscos, ISSN: 0872-8941. 


\section{Introdução}

Esse trabalho foi desenvolvido na área que corresponde às bacias dos ribeirões Doudinho, Panga e Estiva respectivamente. São drenagens afluentes do rio Tijuco, delimitadas pelas seguintes coordenadas geográficas: $19^{\circ} 00^{\prime}$ e $48^{\circ} 10^{\prime}$ de latitude sul e $19^{\circ} 20^{\prime} \mathrm{e}$ $48^{\circ} 50^{\prime}$ de longitude Oeste do meridiano de Greenwich, correspondendo a uma área de 1.301,95 km², da área dos municípios de Uberlândia, Monte Alegre de Minas e Uberaba (MG) (fig. 1). Essa área corresponde ao contato da chapada (área de relevo de topos planos e largos) com o relevo dissecado da bacia do rio Tijuco - MG (área de relevo medianamente dissecada). A origem paleogeográfica da área de pesquisa conta com a evidência tanto de soerguimentos, como de movimentação de subsidência de blocos. Segundo Batezelli (2003), tais processos são consequências dos esforços impostos à placa sul-americana durante a separação Brasil-África.

O município de Uberlândia, segundo Baccaro (1994) foi dividido nos seguintes compartimentos geomorfológicos: i) áreas de relevo medianamente dissecadas, ii) áreas de relevo intensamente dissecadas e, iii)áreas de relevo de topos planos e largos, ou áreas de cimeira (Baccaro 1990), visíveis na fig. 2. A área de pesquisa se encontra inserida na área de relevo medianamente dissecada correspondendo às áreas com topos aplainados com declividade variando entre 2,5 e $5^{\circ}$ na média encosta, de $5^{\circ}$ a $8^{\circ}$ nas vertentes com rupturas de declives sustentadas pelas lateritas e cascalheiras. Segundo Baccaro (op cit). estes topos e vertentes são encontrados entre $700 \mathrm{e}$ $900 \mathrm{~m}$, de vertentes suaves, interrompidas por rupturas locais mantidas pela laterita, onde ocorrem anfiteatros mais convexizados e elaborados, preferencialmente pelo lençol subterrâneo. Os canais de drenagem são sustentados pelos basaltos da Formação Serra Geral e sobre eles estão os arenitos da Formação Adamantina, recobertos por sedimentos Cenozóicos. Os solos nessa unidade são representados pelos latossolos vermelhos escuros álicos ocupando os topos e as vertentes. Os solos gleyzados álicos e distróficos são encontrados nos fundos dos vales, como também nas vertentes entremeados com crostas de laterita, ou cascalheiras (material detrítico), onde aflora o lençol freático, na média vertente. 0 maior número de voçorocas foi encontrado nessa unidade, sendo que do total de 173 voçorocas registradas no mapeamento erosivo do município, 111 foram encontradas na área de relevo medianamente dissecada (QUADRo I).

As voçorocas rasgam espessos pacotes de formações superficiais constituídas por material arenoso

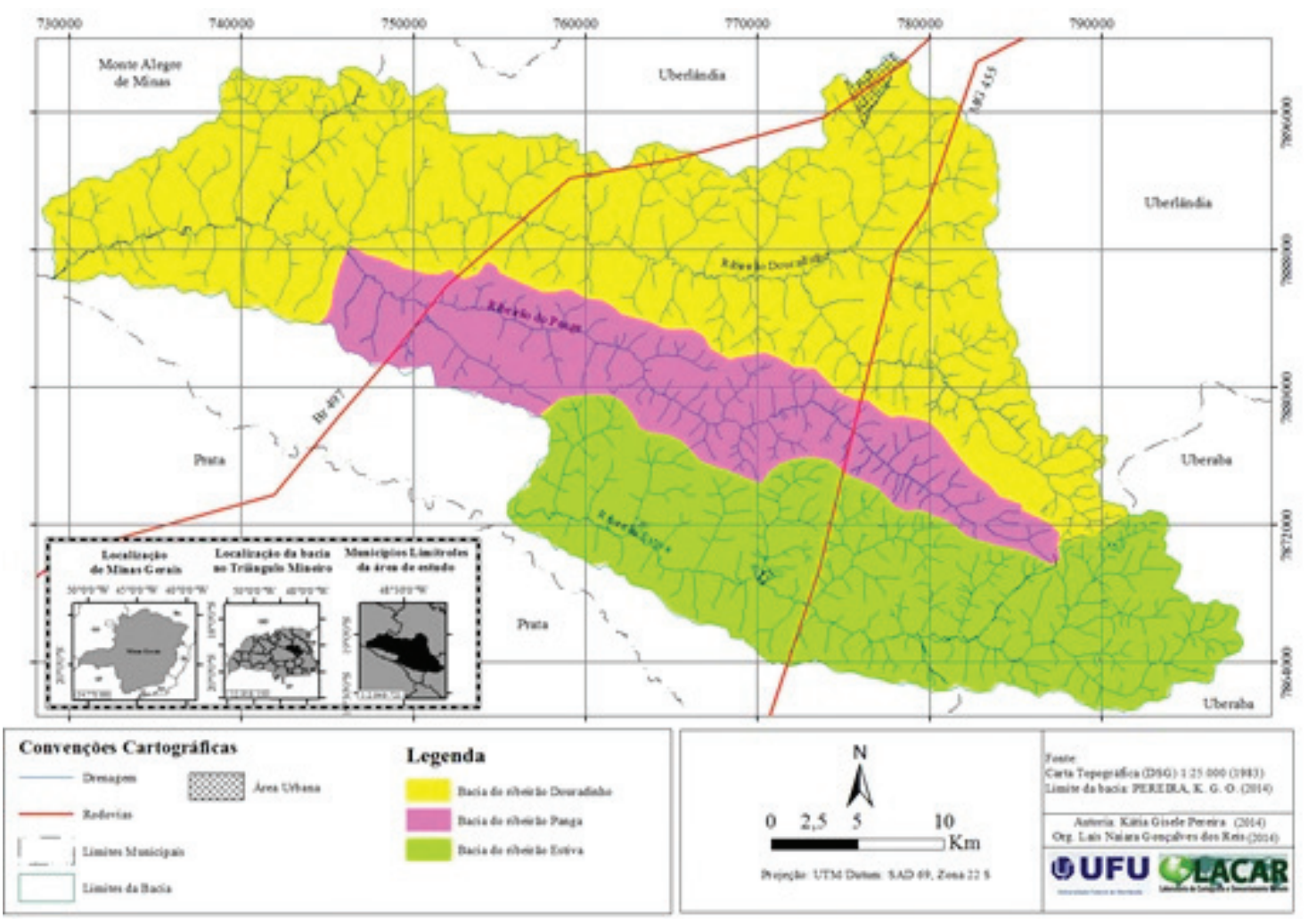

Fig. 1 - Localização da Área de Estudo (Fonte: Cartas Topográficas do Exército, (DSG, 1983), escala 1:25.000).

Fig. 1 - Location of the study area (Source: Military Topographic Maps, (DSG, 1983), Scale 1:25.000). 
predominantemente fino, contendo de 60 a $70 \%$ de areia fina, de baixa compacidade, de cor avermelhada e espessuras variando de 8 a 15 metros, até as camadas superficiais.

QuAdro I - Total de voçorocas na área da pesquisa (1979). TABLE I -Total gullies in the search area (1979).

\begin{tabular}{|c|c|}
\hline $\begin{array}{l}\text { Bacias na área de relevo } \\
\text { medianamente dissecada }\end{array}$ & $\begin{array}{c}\text { Número de voçorocas } \\
\text { ativas (1979) }\end{array}$ \\
\hline Ribeirão Douradinho & 36 \\
\hline Córrego Jatai & 5 \\
\hline Córrego Água Vermelho & 8 \\
\hline Córrego Água Limpa & 10 \\
\hline Ribeirão Panga & 17 \\
\hline Ribeirão Estiva & 35 \\
\hline Total & 111 \\
\hline
\end{tabular}

Fonte: Baccaro (1994). Source: Baccaro (1994).

Em campo, podemos constatar que os pacotes apresentam materiais de diferentes resistências e cimentação. Quando a voçoroca entalha esses pacotes é possível observar que o avanço passa a ser reduzido, ou avançado lateralmente. No desenvolvimento das voçorocas, são encontradas linhas de dutos preferenciais, evidenciando a descontinuidade do material a infiltração da água, que passa a exfiltrar por esses dutos. Também são observados solapamentos basais, movimentos de massas, queda de material e subsidências. Dentro das voçorocas há esporões contornando áreas alveolares abertas por ramificações em dígitos ao longo das vertentes. Os locais preferenciais para o desenvolvimento de voçorocamento são os conjuntos de colinas convexo-côncavas, mais rebaixados em relação a chapada de Uberlândia, com mediana dissecação, recobertos por topos até o fundo de vale, em alguns locais interrompidos por rupturas lateríticas ou cascalhentas. A área de contato com a chapada ocorre a Leste. Ainda segundo Baccaro (1994), os fatores intervenientes para o desencadeamento das voçorocas nesse compartimento geomorfológico foram a retirada da vegetação nativa, uso do solo pelas pastagens sem técnicas de conservação dos solos, abertura de áreas para a construção de estradas, ação da água do escoamento superficial e subsuperficial, formação superficial com alto teor de areia, podendo chegar a $70 \%$ de areia fina, baixo índice de coesão dos solos e desequilíbrio hidrológico das vertentes. Os impactos registrados foram a redução da produtividade agrícola, assoreamento dos vales, redução do manancial de água, danos ecológicos aos solos, vegetação e fauna local.

A área de relevo de topos planos e largos, ou áreas de cimeiras - denominada de Chapada de UberlândiaUberaba, segundo Baccaro (1994) e Schneider (1996) corresponde a topografia de 1000 a $1100 \mathrm{~m}$, com

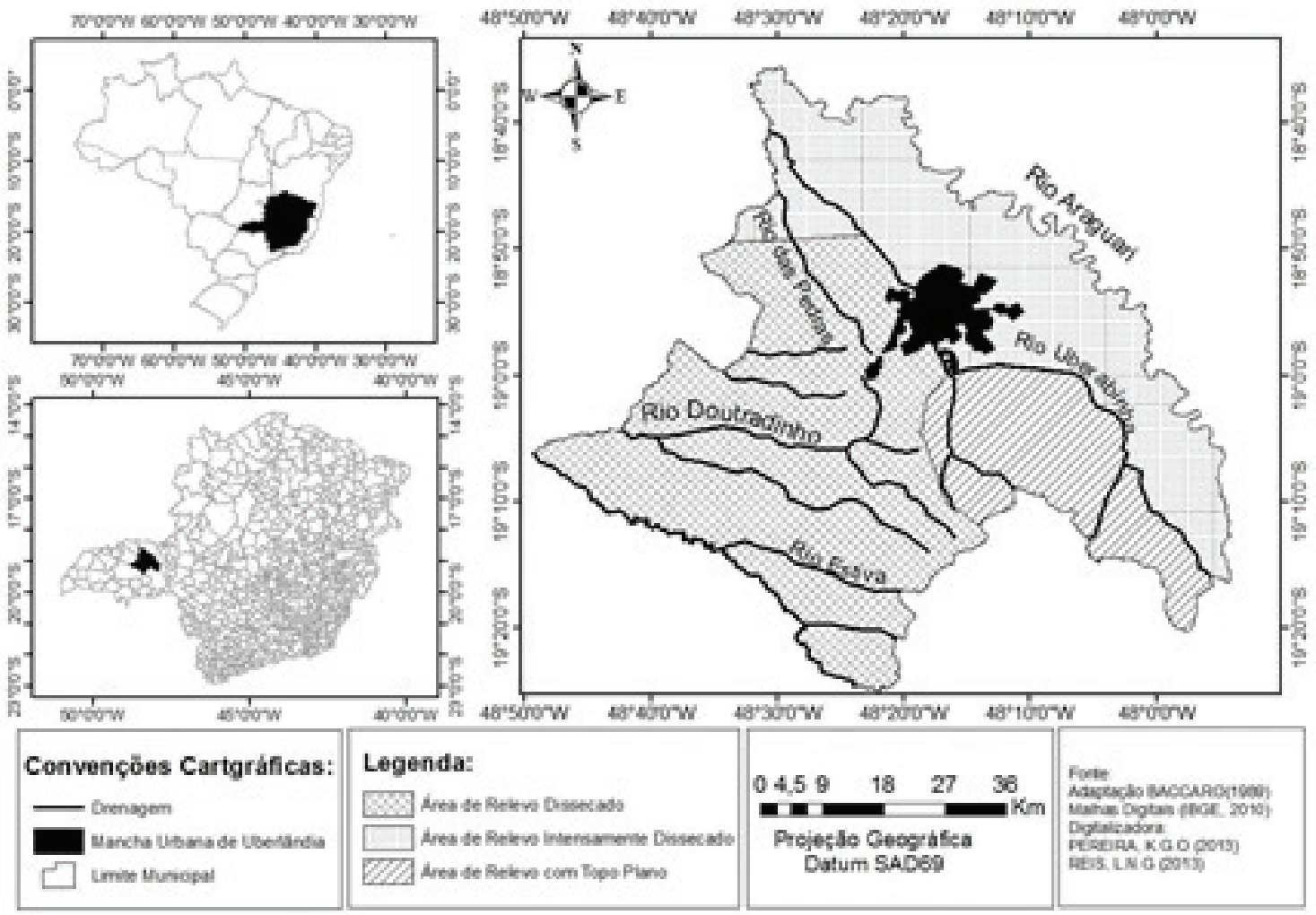

Fig. 2 - Compartimentação geomorfológica do Município de Uberlândia Minas Gerais. MG (Fonte: Baccaro, 1990).

Fig. 2 - Geomorphological partitioning of Uberlândia Minas Gerais Municipality. MG (Source: Baccaro, 1990). 
vertentes longas e planas de declividades menores que $2^{\circ}$, sustentadas pelos arenitos da Formação Marília. Os interflúvios são amplos, podendo chegar a mais de 3 $\mathrm{km}$ de largura. Os vales são rasos, amplos e de fundo achatado, possuem extensas faixas de hidromorfia na borda dos canais. Os processos predominantes são os escoamentos pluviais laminares e difusos. Os solos são alterados e com 85 a $90 \%$ de fração argilosa. O pH fica entre 5 e 6, com saturação de alumínio igual ou maior que $50 \%$ e saturação de bases menor que $10 \%$, rico em óxidos, como a gibsita e a caulinita (fig. 3).

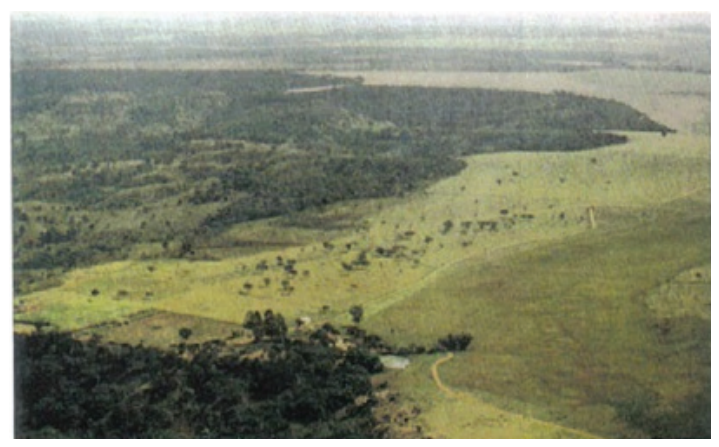

Fig. 3 - Borda sul da chapada no Município de Uberaba, onde se verifica o vale raso do topo plano e o contato com relevo medianamente dissecado pelo aprofundamento da drenagem, no lado esquerdo (Fonte: Schneider, 1996).

Fig. 3 - The southern edge of the plateau in the city of Uberaba , where there is the shallow valley of flat top and the contact with relief moderately dissected by the drainage deepening on the left side (Source: Schneider, 1996).

A origem das voçorocas que ocorrem no município de Uberlândia foi atribuída inicialmente, por Baccaro (1990, 1994) e Guerra e Botelho (1998), aos elevados índices de erodibilidade dos solos; à intensidade das primeiras chuvas de verão - por seu caráter torrencial - seguidas a um período de estiagem, típicos do planalto central brasileiro; ao desmatamento dos cerrados e ao manejo dos solos. Assim, o estudo da geomorfologia estrutural, presente nesse artigo, remete-se, com ênfase, ao estudo da origem e evolução das formas do relevo derivadas direta e indiretamente dos movimentos tectônicos verticais e horizontais, (Facincani, 2000). Devido à necessidade de compreender os voçorocamentos nessa região, foi atribuído seu surgimento aos motivos acima citados, o que remete à gênese antrópica (o desmatamento e o uso desordenado das vertentes), mas também à gênese natural, como o caso do alto índice de suscetibilidade dos solos ao desmantelamento pela baixa coesão entre as partículas do solo, baixo pH. O controle estrutural também é um importante fator condicionante do desenvolvimento do voçorocamento como apontam Coelho Netto Mendonça et al. (2006), Coelho Netto (2003), Abreu, Vieira et al. (2012). Espera-se analisar a forma de atuação da tectônica e dos demais elementos envolvidos na dinâmica de capturas de cabeceiras de drenagem, para a ocorrência de erosões aceleradas associadas às voçorocas, no intuito de explicar a dinâmica de evolução de algumas formas de relevo e das redes de drenagem subsuperficiais.

A análise do comportamento das formas do relevo, dos padrões e da dinâmica da drenagem superficial (escoamento) e subsuperficial podem ser compreendidas por esse aspecto, como aponta (Facincani 2000).

"As descontinuidades estruturais associadas aos regimes tectônicos têm relevante função na origem e evolução das formas de relevo, visto que determinam as vias de percolação da água e aceleram os processos intempéricos (morfogênese e pedogênese)."(Facincani, 2000 p.11).

O desenvolvimento das formas do relevo foi submetido às combinações de atividades tectônicas, das características litológicas, das práticas antrópicas e da dinâmica do clima, obedecendo ao arranjo de escalas que compreendem a bacia do Paraná, até as formas locais como o caso do contato da chapada com o relevo dissecado da bacia do rio Tijuco (MG).

As subsidências descritas para a região Nordeste da Bacia do Paraná ocorreram em função da instalação de intrusões alcalinas que deram origem aos plugs vulcânicos de Tapira, em Araxá-MG, Salitre, Serra Negra e Catalão, o que ocorreu em função do Soerguimento do Alto Paranaíba (SAP), Arco Goiânia e Sutura Itumbiara formando altos estruturais. Ao mesmo tempo, ocorreram subsidências que deram origem a uma nova depressão, alongada segundo a direção aproximada de Nordeste - Sudoeste, que se estendiam do Sul de Goiás, passando pelo Oeste de Minas Gerais, na área correspondente à formação da Bacia do Paraná, mais precisamente na Mesorregião do Triângulo Mineiro e Alto Paranaíba, até ao Sudoeste do Estado de São Paulo, denominando essa depressão como Bacia Bauru. Essa abordagem tectono-sedimentar para evolução da Bacia Bauru já se encontra bastante difundida na literatura geológica presente nos trabalhos de Hasui et al. (1975), Riccomini (1997), Milani et al. (2007), Pereira et al. (2012) (fig. 4). A área de pesquisa se encontra na zona mapeada como depressão Uberaba e as cabeceiras de drenagens das três bacias são encontradas no contato com a Chapada. Essa evolução foi fundamental para o arranjo morfogenético regional, responsável pelo desencadeamento de uma série de processos.

\section{A dinâmica climática com ênfase no verão chuvoso}

Para Novais (2011), o sul do município de Uberlândia, é uma área de clima subquente úmido e semiúmido, o que significa quente durante quase todo o ano, variando de 3 a 5 meses mais secos, nos meses de maio, junho, julho, agosto e setembro. A temperatura média anual fica entre $20^{\circ} \mathrm{C}$ e $22^{\circ} \mathrm{C}$, com temperaturas do mês mais frio entre 


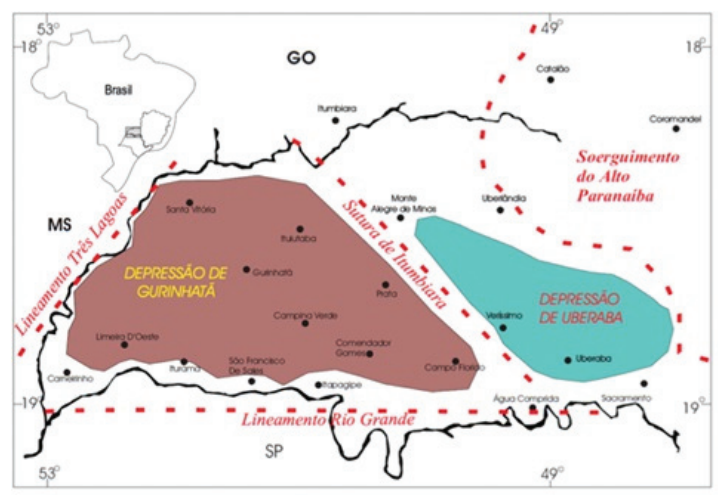

Fig. 4 - Compartimentação Estrutural do Triângulo Mineiro (MG) (Fonte: Batezelli, 2003).

Fig. 4 - Structural subdivision of Triangulo Mineiro (MG) (Source: Batezelli, 2003).

$15^{\circ} \mathrm{C}$ e $18^{\circ} \mathrm{C}$. A pluviosidade média anual fica entre 1.250 $\mathrm{mm}$ e $1.800 \mathrm{~mm}$, concentrada no verão (novembro a fevereiro). 0 déficit hídrico anual fica entre 75 e 200 $\mathrm{mm}$ e o excedente hídrico anual entre 450 e $800 \mathrm{~mm}$. Os totais de chuva são distribuídos irregularmente durante todo o ano, com maior volume concentrado no verão, entre os meses de dezembro e fevereiro com cerca de $50 \%$ das precipitações.

No verão, as massas de ar predominantes que se integra num clima de Massa Equatorial Continental (MEC), das Zonas de Convergências do Atlântico Sul (ZCAS) e da Massa Tropical Continental - Chaco, provocando chuvas na região no sentido NO - SE.

No inverno predominam as Massas de Ar Polar Atlântica (MPA) que promovem a formação de frentes frias. Estas frentes eventualmente provocam o resfriamento da atmosfera, com incidência de chuvas, e a Massa Tropical Atlântica (a MTA continental) fornece aspectos atmosféricos secos e aumento da temperatura, o que caracteriza a instabilidade climática na região (Mendes e Queiroz, 2011).

Ribeiro et al. (1997) destacou que os totais de precipitação vão decrescendo para Oeste (para o Interior), a partir da chapada de Uberlândia, ao longo da calha do Rio Paranaíba, destacando a área entre Cachoeira Dourada e a foz do Rio Tijuco como sendo a área menos chuvosa, em que as precipitações são inferiores a $1300 \mathrm{~mm}$ anuais.

$\mathrm{Na}$ estação chuvosa, predominam as chuvas torrenciais geralmente nos finais de tarde. Essas chuvas são agentes de arrastamento por parte do escoamento superficial, arrastando grande parte de sedimentos, além de agir diretamente no intemperismo das rochas, acarretando processos de alterações geoquímicas. As características do clima como um dos principais agentes modificadores da paisagem, condicionam as alterações das rochas aproveitando os dados da estrutura geológica, demonstrando que têm efeito significativo na modelagem das formas do relevo presentes na bacia em estudo (Baccaro, 1990).

Baccaro (1990), ao descrever as características climáticas do município de Uberlândia, enfatiza a importância dos aguaceiros (chuvas torrenciais) que acentuam os processos erosivos. As fortes chuvas ocorrem no fim do período seco e início do período úmido (setembro/ outubro), em que os solos estão bastante ressecados e sem uma cobertura verde para protegê-los do impacto das gotas da chuva, que se caracterizam por apresentarem um grande poder de carreamento de materiais superficiais.

No período de estiagem, de maio a setembro, os menores índices de chuva foram registrados nos meses de junho e julho, numa média anual de 10 - 15 mm de precipitação. Essa baixa precipitação reduz a umidade relativa do ar, provocando modificações na dinâmica regional. Com a redução da entrada de água no sistema, a paisagem passa por mudanças na vegetação, no solo e no tipo de processo morfogenético e pedogenético (ANA, 2014) (fig. 5).

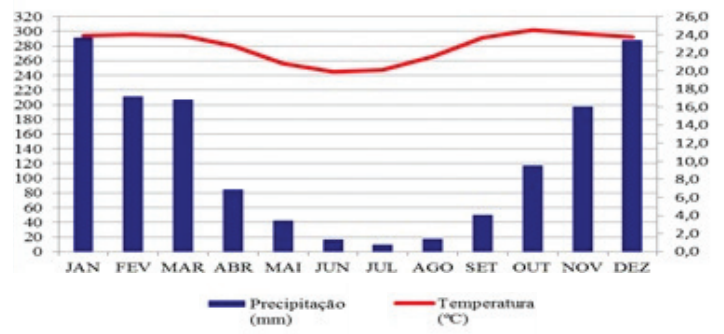

Fig. 5 - Climograma da Área de Estudo, 1976 - 2012 (Fonte: Agência Nacional de Águas - ANA, 2014).

Fig. 5 - Study Area Climography, 1976 - 2012 (Source: National Water Agency - ANA, 2014).

Com a redução das chuvas, ocorre a redução da cobertura vegetal, as pastagens se ressecam ou perdem as folhas, mudando as cores e tons da paisagem. Nos solos, a ausência da água provoca ressecamento e concentração dos óxidos de ferro.

As áreas hidromórficas de média encosta, durante todo o verão, ficam cobertas por vegetação do tipo herbáceo - graminosa, com solos encharcados. No inverno, essas áreas que foram desmatadas se ressecam e se fendilham. Baccaro (1990) relatou que a água das primeiras chuvas após o período seco entra pelas fendas ressecadas erodindo e desmantelando os solos hidromórficos de média encosta, processo que resulta, na maioria das vezes, em surgimento de grandes voçorocas.

O período chuvoso apresenta uma forte concentração de precipitações, pois a soma dos totais médios para os meses de Outubro a Março equivale a um total de $1.312 \mathrm{~mm}$, o que corresponde a um total de $86 \%$ das chuvas anuais. Durante os meses de verão chuvoso ocorre 
o excedente hídrico que atinge $598 \mathrm{~mm}$ e nos meses de inverno ocorre o máximo da deficiência hídrica que fica em torno de 198 mm. (ANA, 2014) (fig. 5 e 6).

Nos meses que predomina o excedente hídrico são os meses que ocorre o aumento da taxa de infiltração, o que também aumenta a taxa de recarga do aquífero, tanto subterrâneo quando superficial. 0 contrário ocorre nos meses de seca (inverno) o que pode significar um rebaixamento do lençol freático (fig. 6).

O clima tem um importante papel na morfogênese, uma vez que a presença da água promove a evolução das vertentes e escavação dos talvegues por meio de fatores interdependentes que abrangem processos complexos de movimento presente na erosão, no transporte e na deposição.

A dinâmica de evolução das formas do relevo responde a um controle dos processos derivados da dinâmica climática, caracterizado pela ação do intemperismo e dos escoamentos superficiais e subsuperficiais. Assim, o padrão climático acima apresentado enfatiza as características tropicais com concentração sazonal da umidade, responsáveis pela intensidade e erosividade de eventos pluviométricos.

O abatimento do nível de base gerado pela ação tectônica e o consequente rebaixamento da topográfica, promovem uma intensificação da ação da drenagem superficial e subsuperficial que age sobre as formas do relevo. A pequena variação da declividade da área e as chuvas concentradas no verão são fatores significativos para compreender a ação erosiva atuando nas formas. 0 que pode ser observado é que a drenagem subsuperficial fica mais concentrada nas áreas de maior declividade, promovendo dessa forma maior escoamento superficial.

\section{O Uso do Solo e a Cobertura vegetal Nativa}

O tipo de cobertura vegetal e as formas das vertentes são também importantes fatores a serem considerados na esculturação da paisagem. A maior densidade da

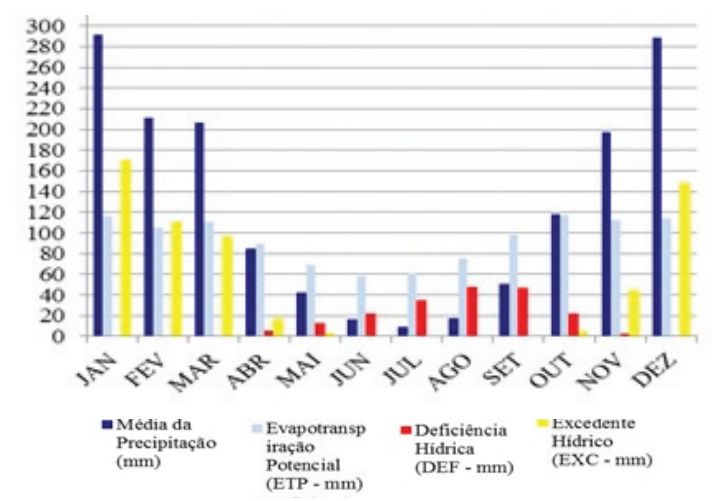

Fig. 6 - Média do Balanço Hídrico climatológico (Fonte: Agência Nacional de Águas - ANA, 2014).

Fig. 6 - Average climatic water balance (Source: National Water Agency - ANA, 2014). cobertura vegetal tanto reduz o impacto da chuva ao solo, como retarda a infiltração, o que diminui a força mecânica da água, favorecendo a ação química. 0 contrário é observado quando há redução da densidade da cobertura vegetal, seja por culturas de cobertura rala como as pastagens, as culturas anuais, ou mesmo a sua ausência, as quais podem provocar o aumento do escoamento superficial com parte do solo podendo ser transportado em suspensão. Nessa situação, tanto o efeito salpicamento, como a rápida saturação do solo e o encrostamento da camada superficial são fatores que aceleram o fluxo de água superficial, o que aumenta a quantidade e a força da água na superfície (Guerra, 2001).

Baccaro (1990) apresenta nos seus estudos desenvolvidos no Ribeirão Douradinho e Panga que a perda de material em suspensão ocorre no período de Outubro a Março, correspondendo ao período chuvoso. No entanto, o total de material em suspensão analisado varia em função do tipo de cobertura vegetal, o período de ressecamento que precede as primeiras chuvas em Outubro, a textura e a estrutura da camada superficial do solo. 0 alto volume do escoamento pluvial também é justificado em função da fina textura desses solos por conter em média $70 \%$ de areia fina, $7 \%$ de silte e $15 \%$ de argila. Em seu estudo foi identificado que o tipo de cobertura vegetal e morfologia das vertentes são importantes para a geração do escoamento superficial. Em área de mata galeria, localizada nos fundos de vales, foi apresentado $14 \mathrm{~mm}$ /diário como limiar para que ocorresse o escoamento pluvial, nas rampas côncavas coluviais revestidas pela vegetação de cerrado o limiar foi de 4 e $8 \mathrm{~mm} /$ diários, nas vertentes convexas o limiar de perda ficou entre 7 e $10 \mathrm{~mm} /$ diários. O que destaca o segmento côncavo da vertente como o que apresentou valores menores de precipitação para que se forme o escoamento pluvial e, também, onde ocorreu o maior volume de escoamento superficial e com maior quantidade de material em suspensão.

Os mapas de uso da terra e cobertura vegetal nativa de 1964 e 1979, com dados presentes no QUADRo II, foram elaborados a partir da fotointerpretação seguindo uma chave de interpretação, baseada nas definições de Rosa (1995), considerando elementos como tonalidade, textura, forma e tamanho. As imagens digitais RapidEye de 2010 foram interpretadas por meio de interpretação visual na tela. 0 mapeamento de uso da terra e cobertura vegetal nativa mostrou uma evolução da atividade agrícola nos últimos 46 anos (1964 até 2010), destacando o uso antrópico e sua relação com as áreas úmidas, ravinas e voçorocas. As fontes disponíveis estavam na escala de 1:60.000 USAF (1964); 1:25.000 IBC/GERCA (1979) e 1:25.000 imagens RapidEyes (2010). Os mapeamentos foram elaborados no sentido de observar o comportamento da morfogênese frente às características do uso do solo e da cobertura vegetal nativa. 
Em função da dimensão das voçorocas e da agressividade com que evoluem, os mapeamentos históricos podem mostrar como a instalação das atividades agropecuárias na bacia pode ter interferência na gênese e evolução das formas.

Para Schneider (1996), a ocupação do cerrado a partir da década de 60 passa a receber incentivos governamentais voltados para a modernização da agricultura. Nos anos de governo militar, a economia brasileira passa para a internacionalização. Para isso, era preciso o desenvolvimento de um pacote de ações financiadas pelo governo, visando o mercado externo. Nesse cenário de expansão da agricultura passa a ter maior destaque. As forças econômicas se unem e passam a investir na ocupação da região central do Brasil, na qual esta pesquisa se desenvolve, portanto as políticas governamentais tiveram responsabilidade no modelo de ocupação e suas consequências. Na intenção de suprir o atraso no campo, foram incentivadas relações capitalistas também neste cenário. Esse processo foi chamado de modernização do campo, em que os pacotes exigiam diretrizes políticas e econômicas para tornar o Domínio do Cerrado produtivo. As relações ditas tradicionais com o campo foram substituídas por relações ajustadas aos modelos econômicos de exploração.

O pacote de modernização exigia o desenvolvimento tecnológico para a correção e adubação dos solos, controle de pragas por meio químico, mecanização do processo produtivo e melhoramento genético das espécies para sua melhor adaptação e, consequentemente, da produtividade. Como o modelo pretendia atender as necessidades do mercado externo, foram valorizadas as características, ou a "vocação" dessas terras e água para a produção Schneider (1996). Vital e Pinto (2009), apontam outro elemento fundamental que da mesma forma que a agricultura precisava desmatar as áreas para a implantação da sua produção. A siderurgia brasileira para tornar o aço competitivo no mercado precisava da produção em escala e de produzir o ferro-gusa a baixo custo. O ferro-gusa é uma liga de ferro carbono utilizada como insumo da produção de aço. Além dessa demanda por madeira na composição ferro carbono, a massa precisa ser aquecida em altos fornos que empregam o carvão mineral (coque) e o carvão vegetal. A dependência por madeira nesse setor da economia tem origem tanto em florestas plantadas como em florestas nativas. Uma forma de obter vantagens comparativas na aquisição da madeira foi o emprego das espécies nativas, uma forma de alimentar os dois setores emergentes da economia nessa fase. Segundo os autores, a possibilidade de empregar insumos sem desembolso imediato, que consiste no uso de madeira das florestas tropicais, cerrados e outras madeiras de matas nativas, acaba gerando uma economia ilusória ou insustentável para a cadeia produtiva. Como a capacidade de regulação e de monitoramento da conformidade das cadeias produtivas e a abundância de vegetação nativa disponível, a questão se agrava.

Outro importante programa de governo foi a implantação do PROVÁRZEA - programa de aproveitamento racional das várzeas irrigáveis, que em 1975 foi piloto no Estado de Minas Gerais e em 1978 foi oficializado pelo Presidente João Figueiredo através do Decreto n.86.146 de 23 de junho de 1981. As várzeas ou áreas de solos hidromórficos e aluviais, são facilmente encontradas nas margens dos cursos d'água, geralmente planos, com maior fertilidade natural, solos inundáveis em locais que o lençol freático aflora, necessitando drenar a área para o aproveitamento agrícola. A lógica do programa era promover a utilização econômica das várzeas em todos os Estados brasileiros por nivelamento dos solos, saneamento agrícola, drenagem e irrigação. Essa medida visava aumentar a produtividade agrícola de alimentos para o mercado interno. Essa foi mais uma alternativa

QuAdro II - Evolução do Uso da Terra e Cobertura Vegetal Nativa.

TABLE II -Evolution of Land Use and Native Vegetation Cover.

\begin{tabular}{|l|r|r|r|}
\hline \multicolumn{1}{|c|}{ Categoria } & \multicolumn{1}{|c|}{1964} & 1979 & \multicolumn{1}{c|}{2010} \\
\hline Pastagem & 840.158 .003 & 941.547 .880 & 753.376 .666 \\
\hline Cerrado & 1.209 .721 .986 & 199.672 .975 & 131.526 .637 \\
\hline Mata & 7.521 .691 & 11.243 .230 & 405.813 .076 \\
\hline Agricultura & 210.768 & 63.583 .264 & 716.699 .947 \\
\hline Sem dados & 77.269 .520 & 28.941 .634 & 0 \\
\hline Formações Hidrófilas & 82.598 .032 & 831.954 .399 & 59.204 .278 \\
\hline Reflorestamento & 0 & 140.536 .617 & 138.799 .157 \\
\hline Área Urbana & 0 & 0 & 12.060 .239 \\
\hline Total & 2.217 .480 .000 & 2.217 .480 .000 & 2.217 .480 .000 \\
\hline
\end{tabular}


para a modernização agrícola. As cartas topográficas do IBGE (1983) refletem essa dinâmica espacial ao apresentar como uso e ocupação das várzeas, áreas de rizicultura, presentes na área da pesquisa.

Embora o programa PROVÁRZEA tenha tido como meta aumentar a pequena produção e elevar os níveis de emprego e renda por aumento da produção e produtividade, Nabuco (2007) avaliou este programa com baixa eficiência no atingimento das metas propostas.

No mapeamento de uso do solo e cobertura vegetal nativa (1964), descrito na fig. 7, predominava a atividade de pecuária que correspondia a $37 \%$ e ocupava as áreas mais baixas das vertentes, os fundos de vales, locais em que predominava a mata estacional decidual. A vegetação de mata que ocupa as áreas de fundo de vale foi suprimida. No entanto, como o uso dos solos tinha necessidade de correção, adubação e manejo adequado para instalação das culturas comerciais, no topo predominava ainda intacta, a vegetação típica de cerrado, ocupando 54\% da área mapeada.

O que chama a atenção nesse contexto histórico foi a supressão da vegetação do tipo mata estacional decidual no fundo dos vales. A análise nos sugere algumas causas para o ocorrido, i) a pecuária tinha necessidade de

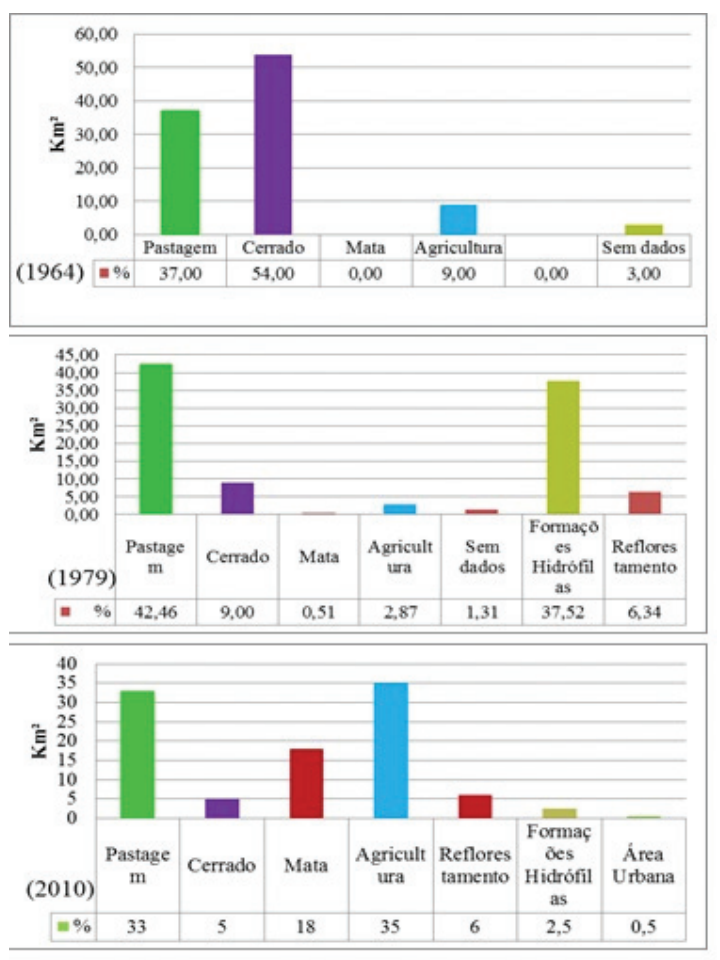

Fig. 7 - a), b),c) respectivamente - Uso da Terra e Cobertura Vegetal Nativa (Fonte: USAF (1964), IBC/GERCA (1979) e RAPIDEYES (2010)).

Fig. 7 - a), b ), c) respectively - Land Use and Native Vegetation Cover (Source: USAF (1964), IBC/GERCA (1979) e RAPIDEYES (2010)). acesso do gado às fontes de água. Acredita-se que a seca nos períodos de inverno demandava por fontes de água para o gado; ii) a necessidade de madeira para o carvão vegetal empregado na siderurgia e iii) o programa PROVÁRZEA, estimulado, financiado e apoiado pelo governo para uso das várzeas foram as principais causas do uso intenso dos fundos de vale nesse período.

O cenário de uso e ocupação da terra, em 1979, presente na fig. 7, demonstra modificações significativas nas áreas e nas atividades do uso e ocupação. A área de pastagem e de cerrado foi reduzida. A atividade pecuária passa a ocupar os topos planos. Observase o início da atividade agrícola, ainda tímida, mas já ocupando áreas das vertentes aplainadas, antes ocupadas pela vegetação nativa.

Dentre os três mapeamentos de uso, este foi o que apresentou significativos resultados para os campos higrófilos, local que o lençol freático aflora, caracterizando os solos hidromórficos, ou solos de várzeas e áreas que afloram a hidromorfia na média vertente, ocupando uma área de $37,5 \%$ da área mapeada. As fotografias aéreas de 1979 têm melhor resolução que as de 1964. A escala das fotos permitiu um melhor detalhamento dessas áreas.

Os campos higrófilos vão aparecer em solos rasos ou laterizados, com cobertura herbácea-graminosa, com espécies das famílias das cyperacea, iridaceae, gramineae, segundo Schiavinl e Monteiro (1991). Devido à boa condição de solo com teores altos de $\mathrm{pH}, \quad \mathrm{a}$ presença de matéria orgânica nas primeiras camadas do solo, tais condições melhoram a qualidade do solo e, com isto, a vegetação de mata apresenta estrutura mais alta, de porte mais robusto, com copas frondosas, troncos mais retos, sendo que as espécies são quase sempre as mesmas encontradas no cerrado típico, tais como ipê (Tabebuia vellosoi), paineira (Chorisi speciosa), aroeira (Myracrochuion), pau d'óleo ou copaíba (Copaífera langslorfi), babaçu (Orbignya speciosa), gameleira (Ficus sp.), buriti ( Mauritia vinífera mart e Mauritia flexuosas). Esse último ocupa as áreas de veredas nos vales de fundo chato e de embasamento impermeável.

Os dados de uso do solo de 2010 demonstram que as atividades agropecuárias passam a somar mais de $74 \%$ da área. A pastagem foi a atividade agrícola substituída por agricultura e cobertura vegetal nativa, passando a ocupar 35\%. Ao longo dos anos, a agricultura passa a utilizar terras nos topos aplainados das vertentes, nos terrenos com baixas declividades, por isso sua maior expansão nos últimos tempos. Dentre as atividades agrícolas, a cana tem ocupado a porção do município de Uberaba e sul de Uberlândia. Em poucos anos ela vem avançando. A mata tem um valor também bem maior, $18 \%$ da área, correspondendo ao cumprimento legal das áreas de preservação permanente. 
De 1964 até os dias atuais, as modificações na lei ambiental possiblitaram aumentarem a área de mata nos fundos dos vales, gerando um aumento na preservação das áreas de preservação permanente (APP's). Esse aspecto teve resultados expressivos no aumento da mata nos fundos dos vales, mas também nas áreas higrófilas ou úmidas. Observou-se que em 1964 essas áreas não dispunham de melhor reflectância nas fotografias, acredita-se que o desmatamento tenha acelerado o escoamento superficial em detrimento da infiltração, por isso as áreas não tinham expressão espectral suficiente para o mapeamento.

Em 1979, as áreas úmidas eram expressivamente maiores e, em 2010, as áreas tiveram a vegetação típica de ambiente mais úmido substituído por vegetação mais robusta, com a mesma resposta espectral que a mata. Em campo, as áreas foram comparadas com as áreas nos anos anteriores e o que se observa é uma recomposição da vegetação com espécies de mata, graças à proteção legal.

Na fig. 8, o gráfico comparativo demonstra a evolução do uso e ocupação do solo e cobertura vegetal nativa, ao longo dos anos mapeados. As áreas de mata aumentaram muito nas áreas das grandes voçorocas, em geral, foram isoladas pela vegetação.

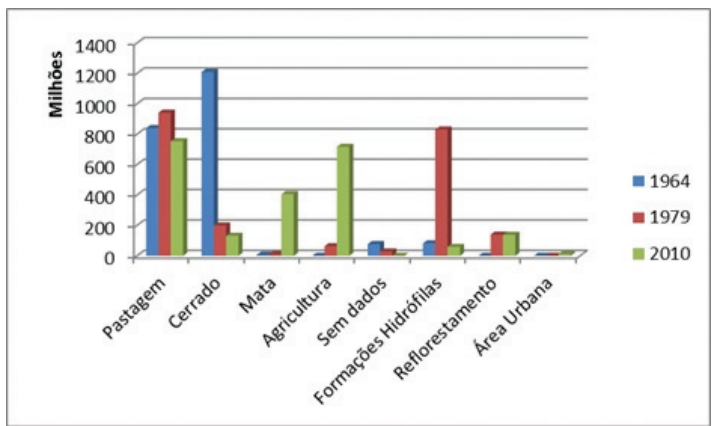

Fig. 8 - Evolução do Uso da Terra e Cobertura Vegetal Nativa (Fonte: USAF (1964); IBC/GERCA (1979); RapidEye (2010)).

Fig. 8 - Evolution of Land Use and Native Vegetation Cover Source: USAF (1964); IBC/GERCA (1979); RapidEye (2010)).

Observou-se que, mesmo com essa proteção, as cabeceiras das voçorocas continuam ativas, inclusive em área preservada.

Esse resultado foi importante, pois reforça a ideia de que para o recuo das cabeceiras dessas drenagens, por avanço da erosão remontante se manteve, mesmo com a recomposição vegetal. Esse aspecto pode reforçar a ideia de que o rebaixamento do nível de base seja uma melhor resposta para o avanço do intenso voçorocamento no compartimento de relevo medianamente dissecado, em função das voçorocas continuarem ativas. Como o nível de base mais baixo em toda a região está no basalto, rocha resistente, difícil de ser escavada, acredita-se a partir daí, que o que ocorre é o rebaixamento do nível de base, ou soerguimento das áreas da chapada, o que exige uma nova acomodação dos níveis de equilíbrio dinâmico entre as novas declividades.

\section{Enquadramento Geológico-Geomorfológico}

A porção norte e nordeste da bacia do Paraná, na qual está inserida a área de pesquisa, tornou-se ambiente de deposição, no período cretácico, por preenchimento da depressão consequente aos altos estruturais por sequência arenosa siliciclástica em clima semiárido, com sedimentos provenientes de alterações e erosão de rochas paleozóicas e pré-cambrianas de área fonte das bordas da bacia. O Grupo Bauru é representado nesta área por: i) arenitos da Formação Marília que foi gerada em sistemas de leques aluviais marginais; ii) a Formação Adamantina que está relacionada com sistemas fluviais de rios anastomosados e planícies com lagoas efêmeras nas porções centro e nordeste da bacia; iii) a Formação Uberaba, restrita ao extremo nordeste da bacia do Paraná, com contribuição de material vulcânico piroclástico.

O embasamento litológico compõe-se de rochas basálticas oriundas do intenso vulcanismo fissural de ocorrência no Mesozóico. Segundo Nishiyama (1989), o basalto aflora no vale dos principais rios e ribeirões em que suas estruturas são expostas pela ação erosiva da água. Os arenitos da Formação Adamantina são arenitos marrom-avermelhados apresentando cimentação carbonática e intercalados por arenitos argilosos e leques de argilitos. Os arenitos da Formação Uberaba são reconhecidos pela contribuição vulcanoclástica de coloração esverdeada e acinzentada. Segundo Batezelli (2003), Almeida e Barbosa (1953), Fernandes (2004) a designação Formação Marília foi empregada para os sedimentos clásticos grossos da parte superior do Grupo Bauru, caracterizados por presença de nódulos e de cimentação carbonática. Os arenitos da Formação Marília são divididos em Membro Serra da Galga e Ponte Alta, o primeiro contém arenitos imaturos, com fácies conglomeráticas de cimentação carbonática (CaCO3) variada e pelos conglomerados. O Membro Ponte Alta contém lentes de calcário silicoso e conglomerado basal e os conglomerados carbonáticos.

A área foi classificada por Baccaro (1991), como sendo de relevo medianamente dissecado em que os topos são nivelados entre 620 e 930 metros, englobando vertentes convexas e suaves, com declives compreendidos entre os $0-2^{\circ}$ nos topos e $10^{\circ}$, no entalhamento das cabeceiras de drenagem.

A maior dissecação observada ocorre nas vertentes em que há sobressaltos com ocorrência da laterita, materiais mais argilosos e cascalheira dos anfiteatros de cabeceiras de drenagens.

No topo da chapada os vales são do tipo vereda, representados por vales rasos (baixa dissecação) e na área do relevo dissecado o grau de entalhamento é bastante expressivo. 0 contato dessa área apresenta 
características de movimentação tectônica, podendo ser a causa do intenso voçorocamento nela instalado. Os esforços de falhamentos dextral E-W geraram deformações na estrutura regional, com regimes transcorrentes na cobertura neocretácia produzindo juntas e falhas responsáveis pelo condicionamento do relevo e da drenagem. Os alinhamentos NW-SE presente nesta região são notáveis no controle da distribuição das rochas do Grupo Bauru e da rede de drenagem regional. Da mesma forma a localização das grandes voçorocas são encontradas nessa mesma orientação entre o contato da chapada com o relevo dissecado.

A suavidade do contato da chapada é rompida por fortes e abruptas declividades. Ora ocorre o avanço da voçoroca, como apresenta na fig. 10 e 11, ora esse avanço se encontra em um rebordo erosivo sustentado por arenitos da Formação Marília, com forte cimentação carbonática. 0 afloramento do nível freático nas áreas de contato demonstra como ocorre a captura da drenagem. No lado da Chapada o afloramento do nível freático se encontra mais alto e na área do relevo dissecado eles estão mais baixos. No entanto a topografia mostra que o nível do freático do relevo dissecado avançou sobre as áreas da chapada. As topografias dos divisores de água do relevo dissecado são as mesmas da chapada. Isso explica que o avanço da erosão remontante vem avançando sobre as áreas da chapada. Neste seguimento há ocorrência de extensas e profundas voçorocas, que variam de 300 - 400 metros de extensão, em que o desnível varia de 30 a 50 metros.

Esse raciocínio evolutivo foi empregado na explicação da existência de significativa quantidade de áreas planas na área de pesquisa. Entende-se, assim, que o soerguimento gerou o material deposicional em formas de leques aluviais para o interior da área, em diferentes condições paleogeográficas.

Por meio dos dados analisados, observou-se que há várias semelhanças com as áreas da chapada, como a predominância de topos planos, ou com baixas declividades da área dissecada.

A área de pesquisa tem uma suave variação da declividade. A fig. 9 apresenta as classes de declividades, nelas observamos que a classe de $0^{\circ}$ a $2^{\circ}$ são encontradas nos divisores de água e nas planícies aluvionares das principais drenagens da área. Essa classe é a que mais predomina, chega a ocupar uma área de $47,2 \%$ do total. 0 que torna essa classe como a mais expressiva da área de pesquisa, conferindo a ela formas de topos planos com camadas litológicas de diferentes resistências à ação do intemperismo e do escoamento superficial e subsuperficial.

Em muitos trechos das planícies aluvionares das principais drenagens dispostas sobre a soleira rochosa basáltica, também predominam baixas declividades. As áreas de topos planos são bastante comuns nas áreas da chapada. As chapadas são superfícies tabulares de bordas com vertentes íngremes ou escarpadas. Apresentam baixas amplitudes topográficas, com baixa declividade e baixa densidade de drenagem.

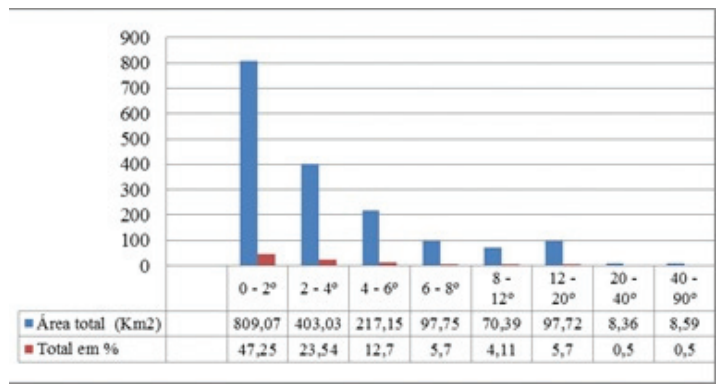

Fig. 9 - Dados das Classes de Declividade (Fonte: Cartas topográficas, (DSG, 1983)).

Fig. 9 - Slope Classes Data (Source: Topographic maps, (DSG, 1983)).

A gênese das formas da chapada e da área dissecada foi a mesma, o que nos leva a pensar que as diferenças entre elas são o levantamento da chapada e o abatimento das áreas próximas, consideradas dissecadas, correspondendo à depressão Uberaba. Esse aspecto evidencia que os blocos que sofreram a subsidência guardaram as estruturas semelhantes de topos planos que os expostos nas chapadas.

Os solos predominantes nas áreas planas do relevo são solos profundos e muito profundos, com horizonte B latossólico, (Baccaro, 1990). São solos em avançado estágio de intemperização, muito evoluídos, apresentando elevada porosidade e permeabilidade interna. A drenagem excessiva ou muito rápida garante maior resistência aos processos erosivos em relação às classes de declividade.

A área predominante que ocupa as classes de $4^{\circ}$ a $12^{\circ}$ correspondem a $22,5 \%$ da área total. Essas declividades são produto do entalhamento do escoamento e estão relacionadas com as vertentes convexas que estão presentes nos vales dos afluentes de toda a bacia. Conforme os dados de declividade observa-se que elas estão concentradas nas bordas das chapadas à Leste e Norte da área, área de escarpas. Na bacia do Ribeirão Estiva ela predomina nos vales das cabeceiras do Ribeirão e nos vales da margem direita. Igualmente é possível observar no Ribeirão Douradinho e Panga a mesma concentração dessas declividades nas margens direitas. Esse aspecto identifica áreas de maior dissecação da drenagem, o que reforça a existência tectônica na movimentação dos blocos, por meio da assimetria das drenagens nesses trechos, destacando as margens direitas com maior inclinação em relação as margens do lado esquerdo. A morfometria da área reforça o caráter tectônico atuando nas vertentes das margens direitas 
das principais drenagens com redução topográfica dos blocos em direção ao Sul (depressão Uberaba), contrário ao entalhamento da drenagem.

A classe de declividade de $12^{\circ}$ a $90^{\circ}$ corresponde a apenas $6,7 \%$ da área, mas é facilmente observada no mapa correspondente. Estas áreas correspondem às rupturas de declives. Segundo Baccaro (1990), no Ribeirão Douradinho e Panga esses trechos correspondem ao aparecimento da laterita, ou concreções ferruginosas presentes na Formação Adamantina, que formam uma laje estrutural de grande resistência à ação erosiva da água.

Alaterita, conforme Espíndola e Daniel (2008), é designada por depósitos residuais endurecidos pelo intemperismo de rochas e materiais superficiais em alteração. São encontrados em posições variadas do relevo, como formam uma laje endurecida são atribuídos a atuação do intemperismo gerado por pedogênese múltipla em solos bem desenvolvidos, sob a ação de paleoclimas.

Para Costa e Olszevsk (2008), nas áreas de concreções ferruginosas é possível observar a presença de minas de água, ou nascentes nesse contato, provando que a drenagem subsuperficial dos solos possui uma direção interna preferencial. A presença e a direção da água no interior do solo são fundamentais para transportar o ferro reduzido, que acumula em ambientes de menor permeabilidade. 0 que no caso, pode ser as diferenças litológicas físicas ou químicas do solo que reduzem sua permeabilidade, como o que ocorre nas descontinuidades presentes na Formação Adamantina. A camada resistente à infiltração impõe movimento lateral da solução, em direção a minas/nascentes, ou hidromorfias de média vertentes. Ao longo do tempo, se forma uma camada desse material pelo acúmulo do ferro oxidado como um cimento. Para esse processo, o clima tropical e a rocha rica em ferro formam as condições ideais, que no verão mobiliza o ferro e no inverno seco ele é precipitado, dando origem a uma couraça ferruginosa.

De forma geral, os solos das áreas mais planas são considerados ácidos, com baixa saturação de bases e elevado teor de alumínio. Nishiyama (1998) assevera que são resultantes de materiais provenientes da Formação Marília e da cobertura detrito - laterítica de idade Terciária. Os tipos distróficos diferem do álico pela sua baixa saturação em alumínio, originado dos materiais arenosos ou argilosos da cobertura detrito-laterítica.

Segundo a EMBRAPA (2006), ocorrem nos municípios de Uberlândia e Uberaba os seguintes tipos de solos: latossolo vermelho-ácrico e distroférrico; latossolo amarelo coeso; glei húmico álico e distrófico.

Os tipos glei húmico, solos típicos de áreas mal drenadas e pouco permeáveis, foram observados nos fundos de vale, nas áreas de topo de chapada, ou nas médias encostas interrompidas por diferenças litológicas, como as rupturas lateríticas. Sobre esses solos Baccaro (1991) descreveu alguns processos erosivos em que o ressecamento dessas áreas ocorre devido ao desmatamento, seguido de fendilhamento dos solos. 0 escoamento superficial nessas fendas pode evoluir para ravinas e voçorocas.

Os solos nos sopés ou nas rampas coluvionadas, que se seguem às bordas escarpadas da chapada, são solos com um teor de carbonato de cálcio maior que os outros solos da região, uma vez que recebem, através de dissolução, tais bases solúveis. Em decorrência de um pH menos ácido e da presença contínua de águas próximas aos contatos litológicos, a vegetação, presente nos sopés dessas serras, é uma vegetação de mata exuberante, (Pereira 1996).

\section{As evidências morfotectônicas no contato da chapada com o relevo dissecado da Bacia do rio Tijuco (MG).}

De acordo com Batezelli (2003), desde o Permiano Superior a Bacia do Paraná deixou de ser uma unidade autônoma de sedimentação, de forma que a deposição Triássica-Jurássico excedeu os limites da Bacia Paraná, estendendo-se para as áreas vizinhas sobre rochas pré-cambrianas e paleozóicas. Dessa forma, a Flexura Goiânia, o Soerguimento Alto Paranaíba teria sido palco de movimentação de falhas transcorrentes (WNW), fruto de tectônica tangencial durante a reativação tectonomagmática Wealdeniana. Sobre essa estrutura então foram depositadas rochas dos Grupos São Bento, os basaltos e os arenitos do Grupo Bauru, condicionadas por falhas com orientação NW - NNW.

A borda Nordeste da Bacia Paraná (local da área de pesquisa) à Leste e a Faixa Móvel do Cinturão Brasília, segundo os dados de registro de sismos do Instituto de Astronomia, Geofísica e Ciências Atmosféricas - IAG/USP, essa região apresentam sismos ativos. Para Cabral (2003), os sismos de origem tectônica que aconteceram numa região são manifestações de atividade neotectônica regional. A ocorrência de paleossismos no período neotectônico considerado pode ser testemunha por provocar evidências, como escarpas de falhas geradas por rupturas superficiais em falhas ativas, fissuras e dobras ao longo dos traços, falhas afetando formações e/ou solos recentes. Segundo Mioto (1990), acredita que em Minas Gerais, "não foi possível estabelecer as províncias sísmicas, ou sismotectônicas, mas tão somente zonas sismogênicas, caracterizadas em termos de tectônica ressurgente e feições neotectônicas, visto que a energia liberada pelos sismos desta região ocorre, preferencialmente, em áreas de notável coincidência com suturas e lineamentos antigos."

Considerando a definição de Cabral (1993), os dados sismológicos encontrados nas proximidades da área de pesquisa, são de sismos atuais que combinam com 
áreas sismológicas das faixas móveis, mantêm-se ativos suficientemente para provocar mudança na superfície e a ocorrência de neotectônica em outras áreas da Bacia do Paraná. Esse aspecto pode sinalizar que a área se manteve ativa nos últimos milhões de anos.

Para Hasui (1990), as feições neotectônicas podem ser obtidas por meio da ocorrência de falhas, aspectos morfogenéticos do modelado, zonas de erosão e de sedimentação, sismicidade, tensões intraplaca e fluxo térmico e fontes termais. Na porção sul do cinturão Brasília, as unidades têm a foliação e empurrões com direção geral NW-SE e mergulhos para o lado SW.

Esses argumentos foram considerados para demarcar uma descontinuidade na movimentação tectônica que se iniciou no Terciário e tem continuidade no Quaternário. Para tanto, analisamos os seguintes pontos: i) o padrão de drenagem para demonstrar as respostas tectônicas no modelado; ii) os sistemas de falhas para identificar o comportamento das vertentes e suas consequências geomorfológicas; iii) os dados morfométricos das bacias com o propósito de demonstrar o rearranjo das formas aos esforços; iv) caracterizar os processos morfogenéticos decorrentes.

A drenagem da bacia do rio Tijuco reflete características do comportamento estrutural próprio do ocorrido na Bacia Paraná. Foi observado nesse estudo que a bacia do rio Tijuco possui orientação NW-SE para os canais principais. Os alinhamentos presentes na área obedecem à orientação NW e NE, como resposta, as drenagens de maior ordem $\left(5^{\mathrm{a}}\right)$ possuem a mesma orientação e as drenagens de menor ordem $\left(1^{\mathrm{a}}\right.$ e $\left.2^{\mathrm{a}}\right)$ ajustam-se no sentido NE-SW e N-S (Corsi, 2003).

Aárea de pesquisa, como afluente do Rio Tijuco, portanto, inserida na referida bacia, aponta características muito semelhantes. As drenagens principais, Ribeirão Douradinho, Panga e Estiva possuem a orientação NW$\mathrm{SE}$, e as drenagens secundárias, NE-SW e N-S.

Para Corsi (2003), os alinhamentos NW-SE, são frequentes na distribuição do Grupo Bauru e da rede de drenagem regional, sendo que esta direção coincide com as marcadas nas rochas do embasamento por processos tectônicos pré-Cambrianos, em função de reativação de antigas falhas. Considerando o que analisa Pedrosa (1989), não se pode pensar que a atual expressão geomorfológica seja explicada por movimentos préCambrianos, mas sim, refletem a reativação sofrida por movimentos tectônicos posteriores.

Assim, foi encontrada similar análise em Corsi (2003), quando aponta que a reativação no desenvolvimento da Bacia Bauru implica em tectônica extensional com distensão NE-SW e formação de falhas principais, mergulhando para o quadrante SW, provavelmente compondo um leque lístrico.
A análise dos perfis geológico-estruturais, de acordo com Corsi (2003), aponta o desmantelamento geral das estruturas e litologias do Terciário no Triângulo Mineiro, fruto dos arranjos tectônicos ocorridos na área, apontando para um abatimento em direção à depressão Uberaba, de forma que os basaltos afloram na cota de $800 \mathrm{~m}$ na bacia do Ribeirão douradinho e por volta de 700m na bacia do Ribeirão Estiva.

$\mathrm{Na}$ análise das drenagens da área de estudo observase drenagens de $5^{\mathrm{a}}$ ordem, com um predomínio de drenagens de $1^{\text {a }}$ ordem, 61\%, com direções NW, NNW, $\mathrm{NE}, \mathrm{SW}, \mathrm{SSW}$ e SE. As drenagens de $1^{\mathrm{a}}$ ordem revelam semelhança com a orientação das fraturas que seccionam os sedimentos presentes na bacia (fig. 10). Os seguimentos de drenagens de $1^{\text {a }}$ ordem podem refletir os últimos eventos tectônicos, uma vez que podem ter relação com as estruturas das fraturas.

Nas drenagens de primeira ordem, são encontradas as áreas de veredas. As drenagens apresentam poucas ramificações, apresentando menor entalhamento, com fundos dos vales chatos, em função de sua ocorrência estar associada a rochas impermeáveis que armazenam água durante todo o ano. Esse aspecto sustenta os campos úmidos que bordejam os buritizais (Mauritias Flexuosas).

Sua ocorrência implica na existência desses fatores geológico-geomorfológicos. $\mathrm{Na}$ área de pesquisa, elas foram identificadas nas elevadas topografias, configurando a existência dos conglomerados e arenitos carbonatados, das concreções ferruginosas e cascalheiras das Formações Marília e Adamantina e no fundo dos vales dos cursos de água principal a ocorrência dos basaltos.

No entanto, foi observado que essas áreas evoluem à medida que a drenagem escava o talvegue. As condições geológico-geomorfológicas são rompidas alterando o regime hídrico, deixando de armazenar água. Esse fato descreve a evolução das drenagens e a substituição da vegetação em condições específicas à sua adaptação,

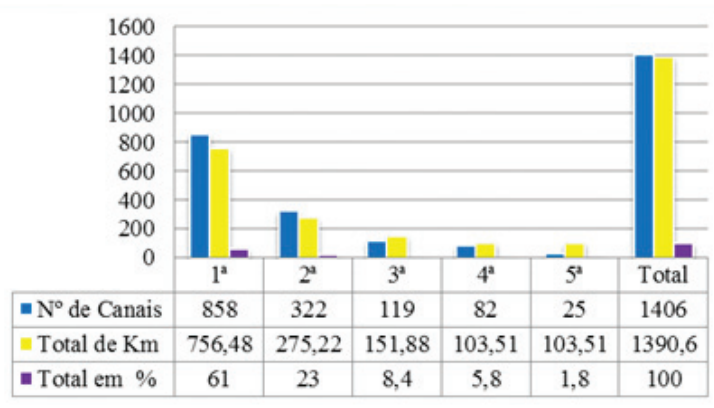

Fig. 10 - Porcentagem Total do Número de Hierarquia de Drenagem (Fonte: Cartas topográficas, (DSG, 1983)).

Fig. 10 - Total percentage of drainage hierarchy number (Source: Topographic maps, (DSG, 1983)). 
acarretando na substituição dos buritizais e campos úmidos, por espécies de mata estacional semidecidual que apreciam ambiente mais drenado.

Essas duas estruturas do relevo, de topos planos e largos e relevo medianamente dissecado, pertencem à mesma gênese, o planalto tabular da chapada na porção Norte e Leste e, ao Sudeste, a depressão Uberaba. Nos cursos d`água principais, as vertentes da margem direita são as mais alongadas, com afluentes mais extensos e que possuem topografias mais elevadas, no sentido $\mathrm{N}-\mathrm{S}$.

Esse aspecto demonstra o ajustamento tectônico que essa área sofreu. Outras evidências topográficas observadas foram a ação da tectônica e a disposição das topografias mais elevadas e de maior declividade ocorrerem na margem direita desses cursos d'água. Assim, a distribuição topográfica aliada aos aspectos tectônicos indica um abatimento dos blocos para o Sul e para o Oeste.

Os aspectos mais expressivos de voçorocamento podem ser relacionados a atividade da tectônica, pois foram encontrados preferencialmente nas bordas Norte e Leste da área. Essa área tem uma forte presença de falhas no sentido N-S, E-W ao norte, N-S e NW-SE, a Leste. As voçorocas encontradas possuem esse alinhamento, o que evidencia a presença de levantamento da chapada e subsidência da área dissecada. Na fig. 4, fica evidente, uma vez que a área de pesquisa se encontra entre a área do Soerguimento do Alto Paranaíba e a Depressão Uberada, descrita por (Batezelli, 2003).

\section{Importância dos fluxos superficiais e subsuperficiais}

Na avaliação do comportamento hidrológico de uma bacia hidrográfica consideram-se as características geológicas como a composição das rochas, o tipo, a ocorrência de eventos tectônicos, as características geomorfológicas (forma do relevo, rede de drenagem, tipo de solos e outros) e as características da cobertura vegetal. Assim, o sistema hidrológico será uma resposta dos conjuntos desses fatores agindo de forma integrada.

Para Summerfield (1991), os padrões de drenagens são influenciados por fatores como variações climáticas e litológicas, no entanto o autor elege a estrutura geológica como uma das mais importantes no seu condicionamento. Os sistemas fluviais sofrem a ação do ajuste de falhas ou deformações regionais, resultando em perturbações, o que torna possível localizar e caracterizar as atividades recentes da tectônica.

Nos períodos chuvosos, as áreas de solos hidromórficos, tanto no fundo de vale quanto na média vertente, respondem às elevadas precipitações pluviais. O fluxo subsuperficial aumenta favorecendo o surgimento de dutos (pipings) facilmente identificados. Nas vertentes e nas paredes das voçorocas essas linhas marcam a descontinuidade presente na constituição litológica de várias composições. As diferenças litológicas marcam material de boa drenagem, interrompidos por camadas de maior resistência a infiltração. Segundo Marinho e Castro (2003), "os dutos podem contribuir para o rebaixamento rápido do lençol freático, pois aumenta o gradiente hidráulico e a remoção de partículas, favorecendo a subsidência em superfície que concentra o escoamento superficial e facilita a instalação ou o desenvolvimento das erosões lineares, que tanto pode ser do tipo ravinamento como voçorocamento, dependendo da profundidade do nível freático. Nesse caso, esse fenômeno promoveria a evolução remontante dos taludes, inclusive dos ramos laterais dos focos existentes."

$\mathrm{Na}$ área de pesquisa, esses aspectos acima mencionados são bastante expressivos. Nishiyama (1989) descreve níveis de lençol freático em diferentes profundidades na área de pesquisa, sua principal justificativa para essa ocorrência são as diferenças de resistências litológicas que favorecem a circulação subsuperficial ativa, tanto na borda da chapada como na média vertente e nos fundos de vales.

As figs. 11, 12 e 13 mostram as voçorocas que avançam sobre as borda da chapada. As linhas marcam o divisor de águas. Na borda das voçorocas as topografias tem a mesma topografia dos divisores de água da chapada. No entanto, as drenagens do relevo dissecado capturaram o lençol freático da chapada. Na fig. 11 mostra o avanço da voçoroca do Tatu (voçoroca do Exército, pois se encontra em área de reserva de Cerrado de propriedade do Exército). A imagem mostra que a cabeceira da voçoroca avançou sob a linha do divisor de águas. Essa voçoroca chega a ter trechos na cabeceira com mais de $30 \mathrm{~m}$ de altura.

Este aspecto demonstra a drenagem superficial para a chapada e a drenagem subsuperficial para a área medianamente dissecada. A origem do intenso fluxo subsuperficial é estrutural, pois favorece a captura subsuperficial da chapada. Na mesma imagem, é possível observar a cabeceira de drenagem da chapada em formato raso de vereda por volta de $858 \mathrm{~m}$, bem próxima da cabeceira da voçoroca em topografia inferior a $850 \mathrm{~m}$.

\section{Considerações Finais}

Nas cabeceiras dos principais cursos de água ocorre a captura de drenagem por recuo das cabeceiras, com captura do fluxo subsuperficial, por rebaixamento do nível de base. Neste compartimento são encontrados intensos voçorocamentos alinhados com as rupturas nas vertentes e, também, com o rebaixamento do nível de base. Os fatores que estão na base da gênese deste processo são diversos: i) forte concentração da precipitação no período chuvoso 
(outubro-março) desta região: ii) ocupação humana pouco ordenada associada ao forte desmatamento que se verificou pós década de sessenta do século passado; iii) a alta susceptibilidade dos solos; iv) a importância dos fluxos subsuperficiais; e v) a tectônica ativa levou a rearranjos morfológicos e, consequentemente, a alterações nos fluxos de drenagem subsuperficiais, com consequências na dinâmica dos voçorocamentos.

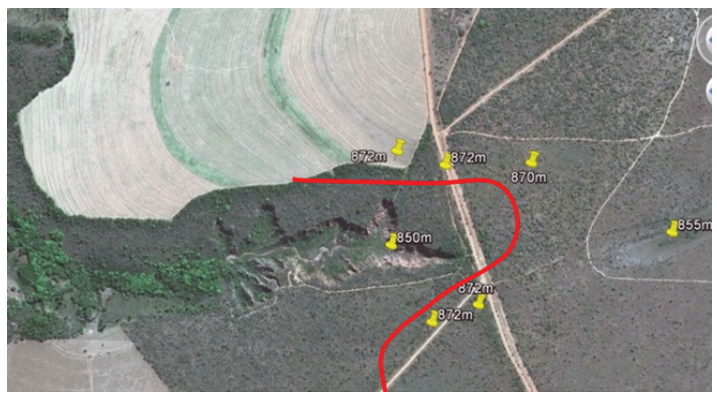

Fig. 11 - Voçoroca do Tatu no Contato com a Chapada, $19^{\circ} 06^{\prime} 21^{\prime \prime} S$ e $48^{\circ} 18^{\prime} 33^{\prime \prime}$ (Fonte: RapidEye, 2010).

Fig. 11 - Tatu Gully in contact with the Plateau, 19 $06^{\prime} 21$ "S and 48 18'33" W (Source: RapidEye, 2010).

\section{Referências}

Abreu, N. R. P., et al. (2012). A relação de Controle estrutural com processos de voçorocamento em Manaus (AM): Uma análise preliminar. Anais do $9^{\circ}$ Simpósio Nacional de Geomorfologia.

Almeida, F. F. M., Barbosa, O. (1953). Geologia das quadrículas de Piracicaba e Rio Claro, Estado de São Paulo. Rio de Janeiro, DNPM/DGM.

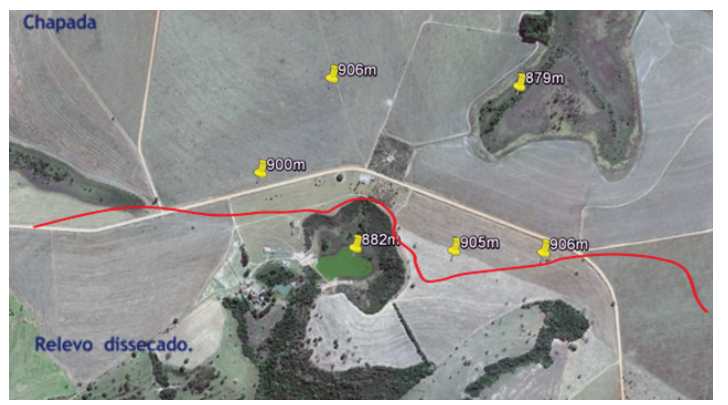

Fig. 12 - Limite da chapada com o relevo dissecado e a direção dos fluxos superficiais e subsuperficiais, $19^{\circ} 10^{\prime} 38.86$ ”'s, 4815'8.39'W (Fonte: RapidEye, 2010).

Fig. 12 - Plateau limit with dissected relief and the direction of surface and subsurface flows, $19^{\circ} 10^{\prime} 38.86^{\prime \prime}$ ', $48^{\circ} 15^{\prime} 8.39^{\prime \prime} \mathrm{W}$ (Source: RapidEye, 2010).

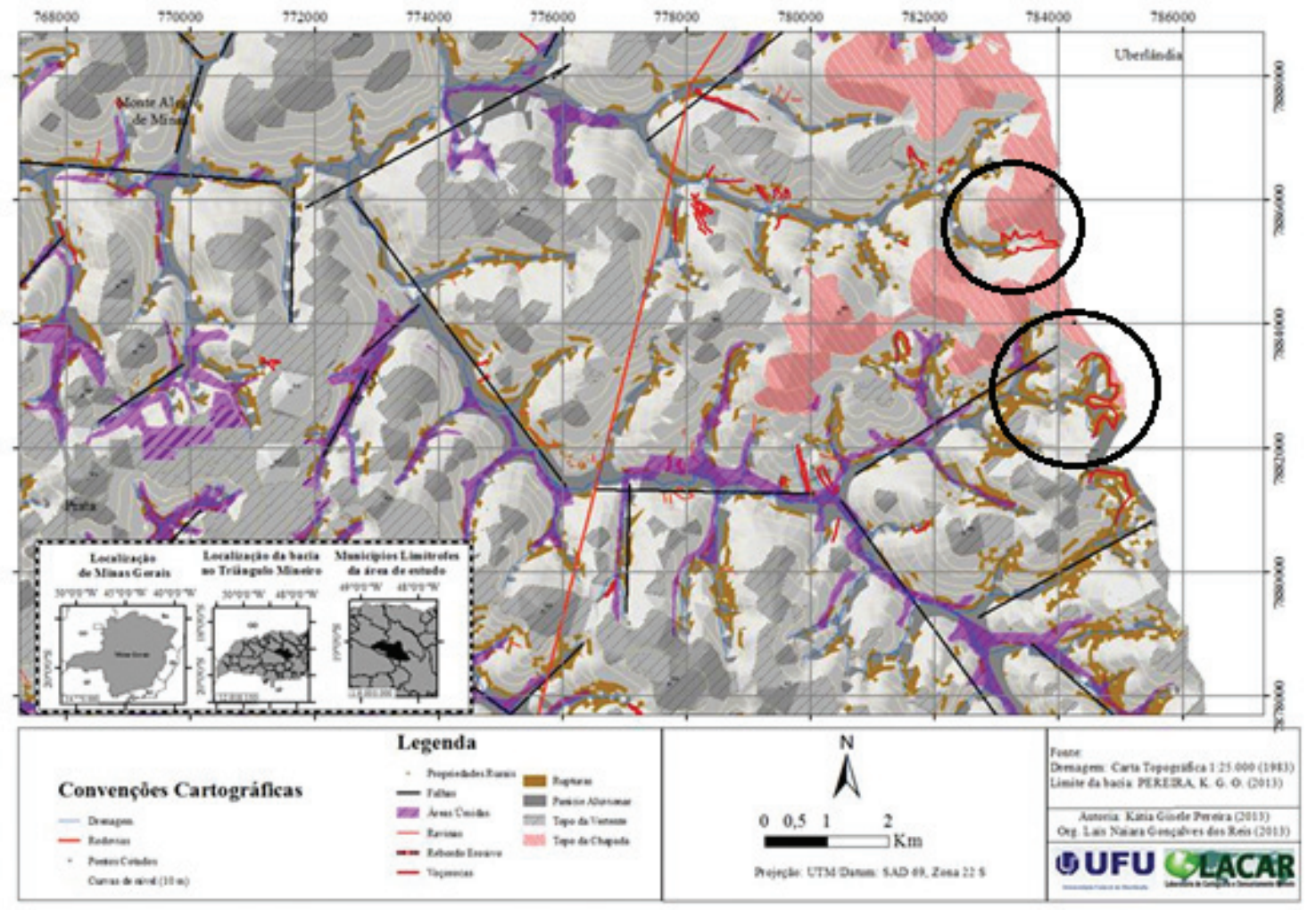

Fig. 13 - Detalhe da área de chapada, no mapa geomorfológico, próximo as voçorocas, figura 11 e 12 (Fonte: Cartas topográficas, (DSG, 1983)).

Fig. 13 - Detail of the plateau area in the geomorphological map, near the gullies, picture 11:12 (Source: Topographic maps, (DSG, 1983)). 
ANA - AGENCIA NACIONAL DE ÁGUAS (2014) . Inventários das Estações Hidrológicas. Sistema de Informação Hidrológica. Acesso em 07/06/2014. http:// www2.ana.gov.br/Paginas/servicos/ informacoeshidrologicas/redehidro.aspx

Baccaro, C. A. D. (1990). Estudos dos processos geomorfológicos de escoamento pluvial em área de cerrado. Uberlândia - MG (Tese de Doutorado). Instituto de Geografia (IG), Departamento de Geografia (DEGEO), Faculdade de Filosofia, Letras e Ciências Humanas (FFLCH). São Paulo, USP.

Baccaro, C. A. D. (1991). As Unidades Geomorfológicas do Triângulo Mineiro. Sociedade \& Natureza. V.(5 e 6): 37-42 p.

Baccaro, C. A. D. (1994). As Unidades Geomorfológicas e a Erosão nos Chapadões do Município de Uberlândia.(MG). Sociedade \& Natureza, n. 11 e 12, p. 19-34, 1994.

Batezelll, A. (2003). Análise da sedimentação cretácea no Triângulo Mineiro e sua correlação com áreas adjacentes. Instituto de Geociências e Ciências Exatas (Tese de Doutorado em Geociências). Rio Claro, Universidade Estadual Paulista - UNESP.

Cabral, J. (2003). A Geologia na Avaliação da Perigosidade Sísmica. Geonovas - APG 17: 21-26FACINCANI, E. M. (2000) - Morfotectônica da Depressão Periférica Paulista e Cuesta Basáltica: regiões de São Carlos, Rio Claro e Piracicaba, SP. 249 p. (Tese de Doutorado). Rio Claro, Instituto de Geociências, Universidde Estadual Paulista - UNESP.

Coelho Netto, A. L. (2003). Evolução de Cabeceiras de Drenagens no Médio Vale do Rio Paraíba do Sul (SP/RJ): A Formação e o Crescimento da Rede de Canais Sob Controle Estrutural. Revista Brasileira de Geomorfologia 2(4): 69 - 100.

Coelho Netto, A. L., et al. (2006). Processos de Voçorocamento no Médio Vale do Rio Paraíba do Sul - Uma questão de Nível de Base. Goiânia. Anais do $7^{\circ}$ Simpósio Nacional de Geomorfologia.

Corsi, A. C. (2003). Compartimentação Morfoestrutural da Região do Triângulo Mineiro (MG): Aplicado a exploração de Recursos Hídricos Subterrâneos. (Tese de Doutorado) Rio Claro - SP: Universidade Estadual Paulista - UNESP: 254 p.

Costa, M. L. e N. Olszevsk (2008). Caraterização da paisagem do Cerrado. In: Savanas: Desafios e Estratégias Para o Equilíbrio da Sociedade, Agronegócio e Recursos Naturais. F. G. Faleiros e A. L. F. Farias Neto. Brasilia, EMBRAPA: 1198 p.
EMBRAPA- EMPRESA BRASILEIRA DE PESQUISA AGROPECUÁRIA. RAPIDEYE AG. RAPIDEYE (2013). Satélite de Monitoramento RAPIDEYE.

Espindola, C. R. and L. A. Daniel (2008). Laterita e solos Lateríticos no Brasil. Boletim Técnico da FATECSP,v. 24: 21 a 24 p.

Fancicani, E. M. (2000). Morfotectônica da Depressão Periférica Paulista e Cuesta Basaltica: regiões de São Carlos, Rio Claoro e Piracicaba, SP. (Tese de Doutorado). Rio Claro, Instituto de Geociências, Universidade Estadual Paulista UNESP. 249 p.

Fernandes, L. A. (2004). Mapa Litoestratigráfico da Parte Oriental da Bacia Bauru (PR, SP, MG), Escala 1:1.000.000 Boletim Paranaense de Geociências, v. 55, p. 53-66.

Guerra, A. J. T., Botelho, R. G. M. (1998). Erosão dos Solos. In: Cunha, S. B. E. G., A. J. T. (Ed.). Geomorfologia do Brasil. Rio de Janeiro, Bertrand Brasil. p.181 - 227.

Hasui, Y. et al. (1975). The Phanerozóic Tectonic Evolution of the Minas Gerais. Anais da Academia Brasileira de Ciência, v. 47, n. 314, p. 431-438.

Hasui, Y. et al. (1995). The Phanerozóic Tectonic Evolotion of the Minas Gerais. Anais da Academia Brasileira de Ciência, v. 47, n. 314, p. 431-438.

IBC - INSTITUTO BRASILEIRO DO CAFÉ. (1979). Fotografias aéreas. Escala 1:25.000.

Marinho, G. V. e Castro, S. S. (2003). Caracterização FísicoHídrica e de Suscetibilidade a Voçorocamento dos Solos da Sub-bacia do Córrego Queixada, na Alta Bacia do Rio Araguaia - GO. Anais do X Simpósio Brasileiro de Geografia Física Aplicada. Rio de Janeiro.

Mendes, P. C. e A. T. Queiroz (2011). Caracterização climática do Município de Ituiutaba. Geografia do Brasil Central: Enfoques Teóricos e Particularidades Regionais. A. P. Portuguez, G. G. Moura and R. A. Costa. Uberlândia, Assis Editora: Assis.

Milani, E. J. et al. (2007). Bacia do Paraná. Boletim de Geociências Petrobras, v. 15, n. 2, p. 265-287.

Nabuco, M. R. A. (2007). (des) institucionalizacão das políticas regionais no Brasil. Revista ETC, espaço, tempo e crítica. ISSN 1981-3732, n² (6), vol. 1, http://www.uff.br/etc.

Nishiyama, L. (1998). Procedimentos de mapeamento geotécnico como base para análises e avaliações 
Novais, G. T. (2011). Caracterização Climática da Mesoregião do Triângulo Mineiro/Alto do Paranaíba e do Entorno da Serra da Canastra. (Dissertação de Mestrado). Programa de PósGraduação em Geografia. Uberlândia, MG., Universidade Federal de Uberlândia.

Pedrosa, A. S. (1989). As Vertentes na Área de S. Miguelo-Anjo: Contributo para o Estudo da sua Evolução. Revista da Faculdade de Letras e Geografia, v, n. 1, p. 83-170.

Pereira, K. G. O. (1996). Os relevos residuais no município do Prata/MG. Departamento de Geografia. Uberlândia, Universidade Federal de Uberlândia. Monografia: 120p.

Pereira, E., Carneiro, C. D. R., Bergamaschi, S., Almeida, F. (2012). A Evolução das Sinéclesis Paleozóicas: Província Solimões, Amazonas, Parnaíba e Paraná. In: Hasui, Y., Carneiro, C. D. R., ., HASUI, Y., Almeida, F. F. M. e Bartorelli, A. (Ed.). Geologia do Brasil. São Paulo, Becca. p.374-394.

Presa, J. B. (2009). Políticas Públicas e o Incentivo a Rizicultura Irrigada no Sul de Santa Catarina: O que foi o PROVÁRZEAS e suas implicações no meio ambiente. Revista História - História. UNICAMP. Acesso em 30/01/2015. http:// www. historiaehistoria.com.br/materia. cfm?tb=alunos\&id=339

Presa, J. B. (2009). A experiência de agricultores em relação à utilização da água na produção de arroz irrigado (1980-2009) - Anais do IV Congresso internacional de história. Maringá. 2009- 2019 a 2030p. Acesso em 30/01/2015. http: / / www.pph.uem.br/cih/anais/ trabalhos/84.pdf

Ribeiro, A. G. (1997). O Papel dos Recursos Hídricos na Sustentabilidade dos Sistema Agroalimentar do Domínio dos Cerrados do Brasil Central. EDUFU. Agricultura, Meio Ambiente $e$ Sustentabildiade do Cerrado Brasileiro. S. e. a. Shiki. Uberlândia. MG.

Riccominl, C. (1997). Arcabouço Estrutural e Aspectos do Tectonismo Gerador e Deformador da Bacia Bauru no Estado de São Paulo. Revista Brasileira de Geociências. v. 27, n. 2, p. 153-162.

Schneider, M. O. (1996). Bacia do Rio Uberabinha: uso agrícola do solo e meio ambiente. (Tese de Doutorado). Faculdade de Filosofia, Letras e Ciências Humanas (FFLCH). Departamento de Geografia (DEGEO). São Paulo, Universidade de São Paulo.

Summerfield, M. A. (1991). Global geomorphology. New York: John Wiley \& Son.

USAF - FORÇAAÉREA DOS ESTADOS UNIDOS. (1960). Fotografias aéreas na escala de 1:60.000.

Vital, M. H. F. and Pinto, M. A. C. (2009). Condições para a sustentabilidade da produção de carvão vegetal para fabricação de ferro-gusa Siderúrgia, BNDES Setorial. 30: 237 - 297. 